\title{
3. From the Theatre As a Cure to the Politics of Performance, Passing Through Social Theatre
}

\author{
Marco De Marinis \\ doi.org/10.3280/oa-637-3
}

\section{Foreword}

The idea that theatre might heal, that it is, or it might be, therapeutic, is as old as the theatre itself. Just think of the theory of catharsis expressed by Aristotle in his Poetics, however enigmatic and elusive it may still be for us. In reality, the theatre's therapeutic potential has traditionally been seen as derived from ritual, the original elective place of efficacy, including and above all curative efficacy. This has proven an idea hard to kill, despite the scientific discredit recently attracted by the theories of the ritual origin of the theatre and, more generally, by all ritual-centralism (Pradier).

Some therapeutic uses of theatre with the mentally ill, the insane, or alienated, as they were then called, are accounted for as early as the $18^{\text {th }}$ and $19^{\text {th }}$ centuries; this is recorded in Peter Weiss's 1964 masterpiece, generally known as Marat-Sade, and its celebrated staging by Peter Brook and the Royal Shakespeare Company in London, in the same year.

But it is undoubtedly in the $20^{\text {th }}$ century that the idea of a healing power of the theatre gathers momentum, within the more general drive towards an effective theatre, able to satisfy requirements and needs different and much more complex than those gratified by traditional pastimes: firstly, educational needs, as seen from the age of the Enlightenment onwards, but also cognitive, social, political, therapeutic. Concerning the latter, Jacob Moreno's psychodrama and sociodrama may be the most widely known examples, but they are not the only ones, with concepts such as "drama therapy", and more recently "dance therapy", gradually appearing (Landy, 1986). This is not surprising, as the body, and more generally physical action, are central to the theatre, dance and mime of the $20^{\text {th }}$ century. Within the theatre and around it flourished several different methods which could be defined as bodily education and re-education, all more or less explicitly therapeutical, such as those practised by Feldenkrais, Alexander, Gurdijeff and Rolf.

Such extra-theatrical methods often reveal a strong resemblance with similar proposals born within the theatre, among others Stanislavski's. Despite being based on the body, they go beyond the mere physical rehabilitation, and have 
the ambition to supply the tools, or the "way", according to the etymology of the word method, for a more general growth of the individual and of their awareness, based on bodily education and re-education. This is the case with Steiner, Feldenkrais, and especially Gurdijeff and his Institute for the Harmonious Development of Man in Paris.

In this context, there is a landslide, a semantic torsion which illustrates the therapeutic function of theatre: from the theatre that cures to a theatre of selfcare, based on the notion and the practice of the work of the individual on themselves. And it becomes clear, as we will see further on, that the relation with the other, with alterity, beginning with our own alterity, the «alterité intime» according to Marc Augé, is always of paramount importance within the various practices which form the work on oneself or self-care.

\section{Theatre and Life, Theatre and Reality, Theatre and Truth}

The trend of attributing to the theatre new, educational, sociopolitical, therapeutic functions and roles, which we have seen in the $20^{\text {th }}$ century, can be analysed from yet another angle. It can also be seen as one of the answers of the time to the irresistible urge to reunite theatre and life, theatre and reality, theatre and truth.

Naturalism had already tried to do so, in its own way. The recipe proposed by naturalism, even though it was born of a shared need, was however soon deemed obsolete by the members of the historic Avant-gardes and above all of the new art of directing. The theatre should no longer be realistic but real, beginning with its creative centre, the actor. The theatre should not so much imitate life but rather be alive, be life. It should not reproduce life and reality but produce it. To put it in more technical terms, the theatre cannot be conceived any longer as mimesis of action, but as action, real action.

It is well-known that this widely shared need has produced different experiences and proposals, putting under scrutiny not only the scene but also everything around it: the historical, social and political reality in which the scene finds itself, like it or not. Do we think we can try to find a formula that summarises all these varied experiences in a unified way?

Swiss director Milo Rau tried to do just so in recent years with his 2018 Ghent Manifesto.

\section{Milo Rau: Ghent Manifesto}

It is a set of ten rules, but the most important one by far is undoubtedly the first one: «One: It's not just about portraying the world anymore. It's about changing it. The aim is not to depict the real, but to make the representation itself real» (Rau, 2018). 
It is worth noticing, en passant, the Marxian opening, which will be the object of a later comment in this paper, which summarises the $20^{\text {th }}$ century utopia of a revolutionary political theatre with its many different declensions (De Marinis, $\left.2020 \mathrm{a}^{4}\right)$. But let us focus ourselves for the time being on the change in perspective which is the primary objective declared by Rau's rule: from representing reality to making real the representation itself. Is this reversal of perspective really able to summarise in one formula the most important innovations of the theatre of the $20^{\text {th }}$ century, those that have changed deeply and perhaps forever our way to think about and make theatre?

At first glance, we would have to say yes, especially if we integrate the Manifesto's first commandment with the following four. For example, the decisive move of the masters of the $20^{\text {th }}$ century from a realistic scenic action to a real scenic action can surely been seen within the reversal of perspective proposed by Rau (De Marinis, 2019 and 2020b).

Taking a closer look, however, we come to understand that Rau's proposal does not encompass many of the most disruptive experiences of the last century, the most innovative ones. This is because the first statement of his Manifesto is still confined to an aesthetical dimension, while it is now clear that the biggest innovations, which are perhaps the only real revolutions of the theatre of the $20^{\text {th }}$ century, were of an ethical nature. They were produced by a theatre which, for the first time, took upon itself demands, ambitions, and social, political, educational, therapeutic, cognitive and even spiritual needs, as we have seen before (De Marinis, 2000).

I would propose therefore an addition to Rau's first commandment, in order to add this crucial ethical dimension to it, an element that is nonetheless present in his theatre: the aim is not to represent reality, but to make the representation itself real, and «to put the representation into reality».

What does «to put the representation into reality» really mean, what has it meant during the last century? It has been another way, equally powerful and often even more, to bring theatre and life closer together, to shorten the gap between scene and life, performance and truth. It is the way that has brought the theatrical fact out of the box, has opened it, expanded it beyond the material and symbolic boundaries which had been customary for centuries. This is the case of the theatre that left behind its traditional places and invaded other spaces, urban and not. This is the case of the «theatre in the space of the clashes» which wanted to have a say on the themes, the times and the forms of the sociopolitical struggle (Scabia, 1973). Think about the phenomena of the agit-prop groups in 1920s and 1930s Europe; about the relationship between

${ }^{4}$ See in particular the chapter Teatro e rivoluzione. Un'utopia del secolo breve e le sue aporie, pp. $49-90$. 
the New Theatre and the Movement in the 1960s in the USA; about Dario Fo's Comune and its direct participation in students' and workers' struggles in 1970s Italy..., all the way to more recent flash-mobs and other collective actions of the last twenty years, involving the Arab world as well, as described by Judith Butler in her Notes towards a performative theory of assembly (2015), to the Fridays for Future and to the movement of the Sardines in Italy. This is the case, as well, of the theatre that goes in search of the non-public and the non-actor, often actively involving them at different levels: from Animazione teatrale 5 to today's participatory and community theatre.

\section{The Non-professional Actor}

Let us stop for a minute to consider the non-actors, that is non-professional actors, as this will enable us to come full circle, getting back to that healing theatre from which we departed. Let us reflect on Rau's seventh commandment: «At least two of the actors on stage must not be professional actors» (Rau, 2018 $)$.

Non-professional actors have always existed, and actually in the $16^{\text {th }}$ century, before professionalism became commonplace, amateurs were the only actors. Today, unfortunately, this term "amateur" has taken on a negative or vaguely derogatory connotation. This is due to the fact that one wrongly thinks exclusively of volunteer, untrained amateur actors, of recreational or parochial groups. This does not take into account the fact that nonprofessional actors have built the history of theatre in the last century. Antoine, for example, was an amateur actor, as was Stanislavski at the beginning of his career, and equally were Paul Fort, Lugné-Poe, Fuchs, Strindberg, Decroux and many more (Taviani, $2005^{7}$ ).

All the agit-prop theatre, which was an enormous phenomenon involving thousands of groups during the 1920s and 1930s, was amateurish: it was made by workers who were enacting a proletarian revolutionary scene. It was therefore a very different theatre from the one produced by the nonprofessional middle-class actors, as described by Béla Balázs at the time:

Who is an amateur? One who does accessorily and inadequately something that others do better professionally. But if one does something

\footnotetext{
${ }^{5}$ For an explanation of the meaning of Animazione teatrale see Notes on Translations on p. 7. The expression is used in this sense throughout the paper.

${ }^{6}$ Translator's note: readers should note the slight difference in meaning between the French expression "peuvent ne pas être" and the English "must not be" (Au moins deux des acteurs sur scène peuvent ne pas être des acteurs professionnels).

${ }^{7}$ Taviani proposes, among other things, the important notion of filodrammatica d'alternativa or alternative amateur dramatics (pp. 284ff.).
} 
that no one else can do better, because no one else does it better, since the matter can only achieve expression through him/her, then he/she is not an amateur (Balázs, 1980, p. 102 of It. translation).

It is worth underlining Balázs's clarification, which identifies as amateurs those who do "something that no one else can do better than» them, and are not, therefore, truly amateurs. We will come back to this later.

From the beginning of the 1970s the distinction between professional and non-professional actors becomes blurred, thanks to the appearance of new forms of theatrical professionalism, which de facto include quite often many of those who would have previously been considered amateurs: from Grotowski's para-theatre to group theatre to third theatre.

From then on, also thanks to the changes introduced by the revolutionary Sixty-Eight Movement, the figure of the professional actor undergoes a radical revision: from the "old school" professionalism, it moves towards a new professionalism, which is defined not only from a technical-expressive point of view but also, and above all, from a socio-anthropological point of view. In this regard, Grotowski's thoughts, when he decides to leave behind forever the mainstream theatre at the end of 1969 , remain to this day among the clearest and deepest (Grotowski, 2002 and 2008).

Neo-professional actors quite often do not make a living from their work and are not therefore professional in the traditional sense of the term even if they perform their job at a high, sometimes very high level of competence and skill, therefore as a true professional craftsman-artist. In terms of today's scene, I am thinking about many representatives of the most recent theatre of the last generations, the so-called Generation 2000 or Third Avant-garde, according to Silvia Mei's definition (Mei, 2015).

If one wants to identify the current example of non-professional actor as described by Rau in his Manifesto, one should look in another direction, and reconstruct a different genealogy, tracing its way back to the working class amateurs of the agit-prop or the group of young people working with Jacques Copeau when he was building the mythical School of the Vieux Colombier (1920-1924).

\section{Genealogy of the Non-professional Actor}

I will choose a few from the many possible examples.

- The young people and adults who worked from 1971 with Giuliano Scabia on his works of Animazione teatrale, which he always preferred to label as «participatory theatre». Among such experiences, notable is 
the one conducted between 1972 and 1973 in the Trieste psychiatric hospital directed by Franco Basaglia, beautifully narrated by Scabia himself in his book Marco Cavallo (1976).

- The two young artists affected by severe disabilities, Raymond Andrews and Christopher Knowles, with whom Robert Wilson worked during the 1960 s and 1970s in the United States, producing extraordinary experiments of visual and sound theatre which were later to become the basis for some of his celebrated performances.

- The spectators who were involved by the Living Theatre in its events, sometimes called "free theatre", based on improvisation and participation. It is worth mentioning that Judith Malina e Julian Beck where among the first, together with Scabia, to take the theatre everywhere, including psychiatric hospitals and prisons.

- The participants of the Theatre of the Oppressed of Brazilian director Augusto Boal, one of the pioneers of the current participatory theatre, from the 1960s.

- Leo \& Perla's "geo-political" actors in Marigliano (Naples), between 1970 and 1978: local factory workers and proletarian, jobless, who had a predisposition to the theatre, according to Leo de Berardinis, due to their Neapolitan roots, their social location and their political activism.

More recently, in my opinion, the phenomenology of the non-professional actor presents two fundamental types: the social actor or the actor of diversity and the testimonial actor.

The social actor, or actor of diversity. I so define people who are disadvantaged, marginalised, physically and/or psychically disabled, imprisoned, or migrant, when they are involved and brought on stage in some theatre projects that have been working for a long time in the field of diversity such as:

- the actors of the Compagnia Pippo Delbono, since 1996, including the iconic Bobò (born Vincenzo Cannavacciuolo), who died aged 82 in February 2019;

- the detainees of the Volterra prison who act in the Compagnia della Fortezza, founded and directed by Armando Punzo over thirty years ago;

- Barbara Voghera, who has Down syndrome, and is the leading actress of the Lenz Theatre in Parma, recently admired in a solo Hamlet;

- the actors with psychic disabilities with whom Antonio Viganò has been creating for years shows of moving truth and beauty (most recently, Otello Circus, 2019). 
The actor testimonial. These are non-professional actors who interpret themselves on stage, normally mixing with professional actors, and often tell first-hand stories, big or small, almost always featuring episodes of violence, oppression and injustice, of which they were protagonists, victims or witnesses:

- Milo Rau's non-actors, who in his shows creatively "reactivate" episodes of recent European or world history such as the massacres in Rwanda or Congo, the Moscow trial against the Pussy Riot activists, the farcical trial against the Ceausescus in Romania.

- Lola Arias's non-actors: the Argentinian actor-director, who has worked extensively in Europe and is the undisputed leader of the artistic operation called «re-enacting life» (Arias, 2019), in her Atlas des Kommunismus (2016) has reconstructed the history of the GDR from the post-war period to the present day, bringing on stage women from different generations who have experienced it in different times, roles and at different levels ${ }^{8}$.

- The non-actors of the German group Rimini Protokoll and their director Stefan Kaegi, who in Granma (seen at the Bologna Arena del Sole in April 2019) recounted the Cuban revolution, and its "betrayal", with the voices and bodies of people of different generations (but belonging to few family groups) who fought it, defended it, suffered it, criticised it, and overcome it.

- Among the most recent Italian examples, it is worth mentioning Mario e Saleh (2019), by Saverio La Ruina from Scena Verticale (Castrovillari), based on his own dramaturgy: the role of a North African immigrant forced to share a tent with a man from Calabria after an earthquake, is played by Chadli Aloui, a migrant from Maghreb, who transfers his painful and difficult personal story into the fictional one, giving it a more problematic authenticity. The beautiful Gospel by Pippo Delbono (2016), later made into a movie, featured migrants both on stage and in video, and attracted a growing number of migrant spectators in the following runs, building up a significant presence in the audience. The works of a young director from Bologna, Nicola Borghesi, leader of the Kepler 452 group, which often use non-actors taken from real life, to make them the protagonists of investigations (on love, for example), or to drop them into dramatic fiction, as in the case of a recent The Cherry Orchard (2018), where instead of Ljuba and Gaiev there was a couple of disadvantaged

\footnotetext{
${ }^{8}$ In another very important work of the same year, Minefields, Arias brought together six veterans of the Falkland/Malvinas war (1982), three British and three Argentineans, to recount that forgotten conflict, which nevertheless represents an open wound in the collective memory of the South American country.
} 
old people from Bologna who had recently been evicted from their home of thirty years and had been reduced to an even more precarious existence as homeless 9 .

\section{Conclusions: From the Theatre as Art to Theatre As Social Practice}

What I tried to draw broadly and with some examples is a rich and diversified phenomenology of theatrical experiences which, by several means among which the use of non-professional actors, try to take Rau's proposal to make real the representation one step further, inputting the representation into reality. As I have mentioned earlier, one has to bear in mind that even if Rau does not explicitly express this intention, it is not absent from his theatre work and his Manifesto. It is not a coincidence that his ninth commandment prescribes that: "At least one production per season must be rehearsed or performed in a conflict or war zone, without any cultural infrastructure» (Rau, 2018).

This is perhaps the only way in which today, after the decline of the revolutionary utopias of the $20^{\text {th }}$ century, one can realistically articulate the Marxian imperative (in reality the Marx-Engels imperative) with which Rau, as we have seen in the beginning, opens his Manifesto.

Today, changing the world through the theatre can mean this, modestly but concretely: to bring to life actions that, however small and intermittent, use the tools of the theatre in its widest meaning, as an antidote to fight (cure, once again) the great anthropological problem of modern humanity: the fear of the other, of the different, of the foreigner, as this has become recently the object of unscrupulous political speculation, relentlessly manoeuvring to transform this fear into anger and hatred. The latter is a political strategy which philosopher Donatella Di Cesare recently named "phobocracy" (Di Cesare, 2020).

It is quite evident that this fear and consequent hatred are linked to the current, impetuous resurgence of racism and fascism throughout the world, taking the form of nationalist populism. Needless to name names, we all know them. With all its limits, the theatre can do a lot in practice to fight these fears and phobocracy. A small example that I have been lucky enough to witness personally, just a few weeks before the pandemic broke out, is Pietro Floridia and his Cantieri Meticci's theatre project, conducted in

9 The subtitle was Trent'anni di felicità in comodato d'uso (thirty years of borrowed happiness). In his last work Perdere le cose (losing things, 2019), the painful story of an illegal immigrant constantly waiting for a residence permit, told by two actors, culminates with its (awaited) final epiphany, painstakingly negotiated time after time, apparently, with the local police headquarters. 
Bologna in 2019 with young Italians and African immigrants, based on Conrad's strong and ambiguous short story The Nigger of the Narcissus.

In my most recent book (De Marinis, 2020a), I talk about experiences like these in terms of a politics of performance which fights the current performance of politics, that is phobocracy, with the specific weapons of theatre, of a theatre that not only makes real the representation as recommended by Rau, but more and above all tries to input representation into reality.

But which is the theatre suitable for a politics of performance? I have mentioned more than once the need to conceive and practice the theatre in its widest sense, according to the rich legacy of the last century, in short, a very broad spectrum theatre, we could say, paraphrasing Richard Schechner's well-known definition of performance. By way of conclusion, it is necessary to add some further, decisive clarification, in view of the theatre of tomorrow.

Going forward, the contribution that theatre as art could give to a politics of performance will be more and more reduced in my opinion. And this is so regardless of the quality of the works that it will produce. After all, for a long time theatre as art has been a prisoner of an increasingly restricted, closed, self-referential horizon of fruition, something that among other things makes it less and less appealing for public and private financing in terms of political gain or publicity.

In reality the theatre as we have predominantly known it until now, that is as a specific, highly specialised, artistic practice, could be doomed or have a very precarious future, in which only the most commercial forms will survive. Personally, I do not see any reason to be happy, quite the opposite. However, in the face of such momentous tendencies, there is little to do but to try to save what can be saved.

On the other hand, at the same time, I am equally convinced that there will be more and more need in the future of the theatre as a widespread yet rigorous social practice, deeply (biologically?) rooted in the nature of the human being (social animal or zoon politikon). Even if art will not be the theatre's primary aim any longer, it will not be able to do without the rigour, creativity and professionalism of the best art theatre. Therefore, as far as I am concerned, no cheap amateurism or spontaneity. In fact, the most qualifying experiences in the field of social theatre, or of the theatre of social interactions (Meldolesi), experiences that in my opinion are becoming one of the forerunners of a politics of performance, have been demonstrating for quite some time that social efficacy and aesthetic efficacy go hand-in-hand, so one cannot exist without the other (Porcheddu, 2017; Porcheddu and Carponi, 2020). 
I would quite like to finish, hoping you will forgive me for this selfquotation, with the concluding lines of my most recent pamphlet on performance policy:

the theatre as a widespread but rigorous social practice, rather than as art, will be very important, maybe even essential, to the life of future communities (De Marinis, 2020a, p. 132). 